\title{
EFFECT OF PRESS CONSTRUCTION ON YIELD OF PRESSING AND SELECTED QUALITY CHARACTERISTICS OF APPLE JUICE
}

\author{
Zbigniew Kobus ${ }^{1}$, Rafal Nadulski ${ }^{1}$, Alexandros Sotirios Anifantis ${ }^{2}$, Francesco Santoro ${ }^{2}$ \\ ${ }^{1}$ University of Life Sciences in Lublin, Poland; ${ }^{2}$ University of Bari Aldo Moro, Italy \\ zbigniew.kobus@up.lublin.pl,rafal.nadulski@up.lublin.pl, alexandrossotirios.anifantis@uniba.it, \\ francesco.santoro@uniba.it
}

\begin{abstract}
The process of fruit juices production should be characterised by a high efficiency, while the final product should have a high content of soluble solids, low acidity and a high content of health-promoting components. Currently, screw presses are becoming increasingly popular especially on small farms and households. Their construction has a great impact on yield pressing and quality characteristics of juice. The primary objective of this study was to determine the effect of the press type on juice extraction efficiency and on the total amount of released polyphenols. The scope of the study included also the determination of the juice quality parameters such as the content of soluble solids, $\mathrm{pH}$, viscosity and density. Apple fruits were pressed using two types of machines: a single-screw press and a twin gear juice extractor. Study results demonstrate that the pressing efficiency depends on the press construction. The highest yield of extraction was obtained for the twin-screw press. Under the experimental conditions, there was no influence of the press type on the quality properties of the juice, except for its viscosity. However, the quality characteristics of the juice depended on the apple variety. Higher contents of the extract and polyphenols were obtained in juice from the apple var. Jonagold juice and viscosity in juice from the apple var. Ligol juice. The use of the press offers the possibility of producing juices with desirable quality traits.
\end{abstract}

Keywords: juice, yield, juice quality, press construction.

\section{Introduction}

A growing interest of consumers has recently been observed in health-promoting foods, which lower the risk of development of certain diseases and disorders [1]. One of the classes of chemical compounds with documented health-promoting properties are polyphenols [2].In Europe, a common source of these compounds are apples. They are eaten either fresh or processed, mainly in the form of juices. In recent years, there has been an increase in the consumption of natural juices (NFC - not from concentrate), i.e. with a low degree of processing [3]. The technological process of apple juice production on the industrial scale includes washing, inspection, mashing, enzymatic liquefaction, extraction, thermal treatment, depectinisation, clarification, filtration, pasteurisation, and packing [4].

Under industrial conditions, juices are produced with the pressing method mainly by using the horizontal rotary press, as well as belt and screw presses and with the help of centrifugal separation of juice from a continuous fruit mash stream. In this industry, great attention is paid to workers safety and health evaluation like in other agroindustry and agricultural sectors [5-7]. The method of pulp processing and the method of juice production as well as the parameters of these processes have a major influence on the efficiency and quality of the juice obtained [8]. The health-promoting value of apples is related among others to the content of polyphenols and soluble fractions of dietary fibre. Improperly selected production technology can significantly reduce the health-promoting value of juices. Today, juice producers, especially those operating on a small scale (orchardists, local entrepreneurs), specialize in the production of natural cloudy juices. Their processing does not involve enzymatic treatment of pulp, clarification and filtration, which allows for the preservation of a greater amount of pectins and polyphenols than in clear juices produced from the same raw material [9].

The process of fruit juices production should be characterised by a high efficiency, and result in the final product with a high content of soluble solids, low acidity and a high content of healthpromoting components. Nowadays, screw presses are becoming increasingly popular especially on small farms (in which renewable energy can be used to supply energy [10]) and in households. The construction of these presses has a great impact on the pressing yield and probably on the quality characteristics of juice. Currently, there are limited reports concerning the physico-chemical composition of apple juices processed by different extraction techniques.

The aim of this study was to determine the effect of the press type on juice extraction efficiency and the total amount of released polyphenols. The scope of the study included also the determination of the juice quality parameters such as the content of soluble solids, $\mathrm{pH}$, viscosity and density. Fruits 
of apples of two varieties: Jonagold and Ligol, were pressed using two types of machines: a singlescrew press and a twin gear juice extractor.

\section{Materials and methods}

The research was conducted with applies ofLigol and Jonagold varieties purchased from the Rylex Group sp. z o.o. (Błędów, Poland). The tests were conducted on healthy fruits, without any mechanical damage. Prior to the tests, the fruits were washed, dried on blotting paper, and divided into portions of $200 \mathrm{~g}$ each. Two kinds of presses were used for juice extraction: a single-screw press (Zelmer, Poland) and a twin gear juice extractor (Green Star Elite 3000, Tribest). The extracted juice was collected in containers and stored in a cold place.

\section{Pressing yield}

For both presses, two types of pressing yield: pressing yield for raw juice $\left(Y_{r}\right)$ and pressing yield for filtered juice $\left(Y_{f}\right)$ were determined in accordance with the following formulas:

$$
Y_{r}=\frac{m_{j}}{m_{a}} \cdot 100 \%
$$

where $Y_{r}$ - pressing yield for raw juice

$m_{j}$ - mass of raw juice

$m_{a}$ - mass of apple

$$
Y_{f}=\frac{m_{f}}{m_{a}} \cdot 100 \%
$$

where $\quad Y_{f}$ - pressing yield of juice after filtration

$m_{f}-$ mass of filtrated juice

$m_{a}-$ mass of apple

\section{Total phenolic content}

The total phenolic content was determined according to the FC method [11]. The absorbance was measured using a spectrophotometer (UV-1800 Shimadzu, Japan) at a wavelength of $\lambda=760$. The results were expressed as $\mathrm{mg}$ gallic acid equivalent per $100 \mathrm{ml}$ apple juice (mg GAE per $100 \mathrm{ml}$ ).

\section{Antioxidant activity $(\boldsymbol{A A})$}

Antioxidant activity (AA) of juices wasdetermined by the method of reduction of the synthetic 2.2-diphenyl-1-picrylhydrazyl (DPPH) radical and by spectrophotometric absorbance assay according to the modified method of Brand-Williams et al. [12]. The absorbance of the solutions was measured at a wavelength of $\lambda=517 \mathrm{~nm}$. Degree of inhibition was calculated from the following formula:

$$
A A(\%)=\frac{\left(A_{c}-A_{s}\right)}{A_{s}} \cdot 100 \%
$$

where $A A$ - antioxidant activity, \%

$A_{c}$ - control absorbance

$A_{s}$ - sample absorbance

\section{Soluble solids content, juice acidity and density}

Soluble solids content in the juice was determined with a refractometric method (PN-90/A75101/02), using an ATAGO PAL-3 refractometer (Atago, Tokyo, Japan). Juice acidity was determined with a pH-metric method (EN 1132: 1994), using a CP-411 pH-meter (Elmetron, Zabrze, Poland). Juice density was determined with the use of a pycnometric method at a temperature of $22{ }^{\circ} \mathrm{C}$, using distilled water as a model liquid.

\section{Dynamic viscosity}

The viscosity of juice was determined using a rotational type Brookfield Viscometer (Model LVDV-II Pro +, Brookfield Engineering Laboratories, USA). A juice sample of $16 \mathrm{ml}$ was pouredinto 
a cylindrical chamber (ULA) and allowed to equilibrate at the desired temperature using a circulating water bath. The viscosity of apple juice was measured at a temperature of $22{ }^{\circ} \mathrm{C}$ at $50 \mathrm{rpm}$.

\section{Methods of statistical analysis}

Statistical analysis of the data was performed with Statistica software (Statistica 12, StatSoft Inc., Tulsa, Okla., U.S.A.) using analysis of variance for factorial designs (ANOVA). The significance of differences was tested using the Tukey LSD test $(p \leq 0.05)$.

\section{Results}

The statistical analysis of the results revealed a statistically significant $(p \leq 0.05)$ effect of the press type on the yield of the pressing process. Generally, the juice extracted with the screw presses is characterized by a high content of pulp particles in comparison to the juice produced on basket or layer presses. Hence, the juice needs to be filtered before further processing. Under the conditions of the experiment, in the case of raw juice, juice pressing witha twin-screw press resulted in an increase of the process efficiency by approx. $22.5 \%$ in comparison to a single screw press (Fig. 1). However, in the case of filtered juice, an increase in the pressing yield was observed by approx. $63 \%$, if compared to a single screw press (Fig. 2). The higher efficiency of pressing is due to a different and more effective way of fruit grinding in the two-screw press. The twin gear press (or the triturating juicer) crushes and grinds the material into very small particles (smaller than in the case of the singlescrew press). Also, the triturating extractor causes wider opening of the cell membranes and release of greater amounts of their deep-seated nutrients. There was no influence of varietal characteristics of the tested apples on the pressing yield.

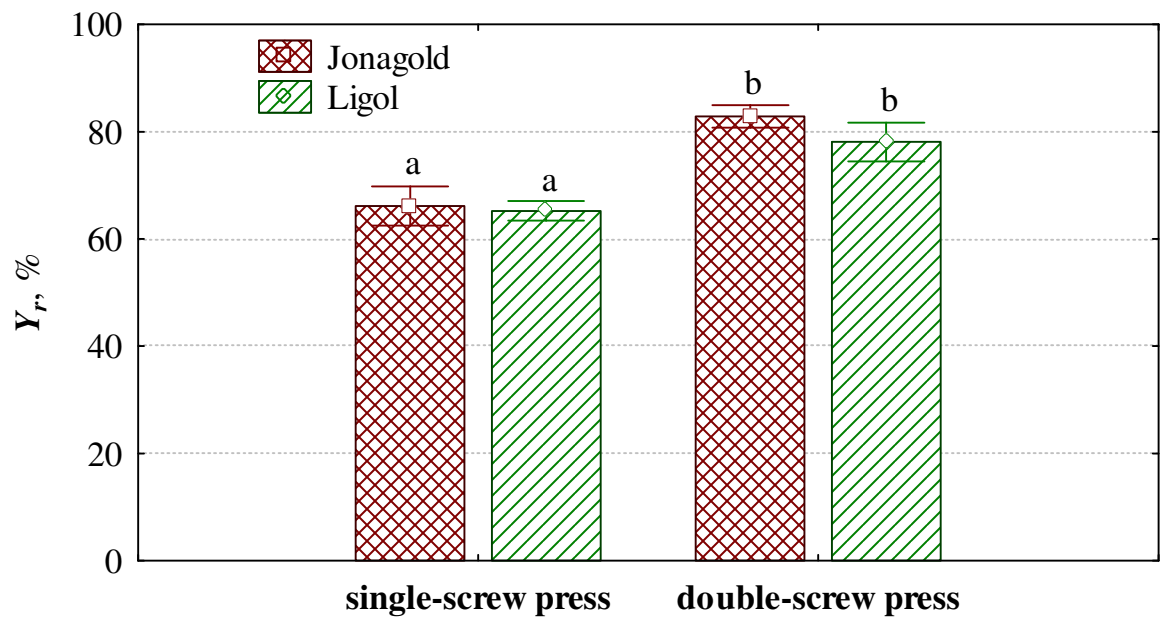

Fig. 1. Effect of press type on yield of pressing $Y_{r}$ (unfiltrated juice)

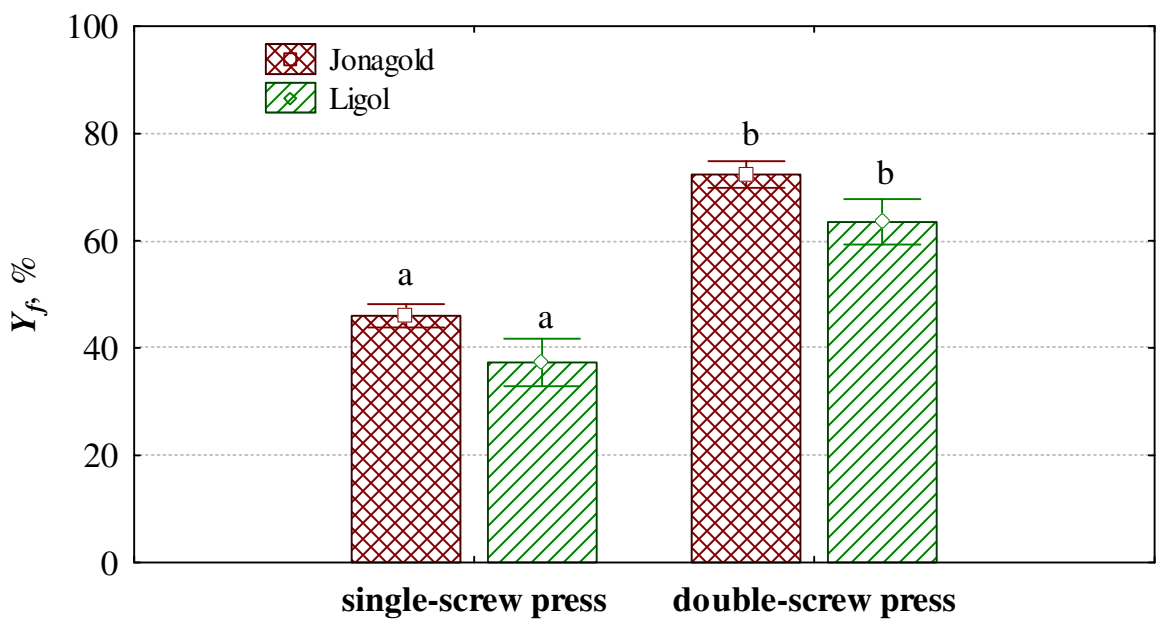

Fig. 2. Effect of press type on pressing $\boldsymbol{Y}_{\boldsymbol{f}}$ (filtrated juice) 
The conducted analyses showed no influence of the type of the press on the content of polyphenolic compounds in the extracted juices (Fig. 3). The content of these compounds was affected only by the varietal characteristics of apples. This is consistent with the literature data $[13 ; 14]$ : regardless of the type of the press used, the content of polyphenolic compounds in the apple juice from the Jonagold variety was by about $20 \%$ higher compared to the juice from the Ligol variety.

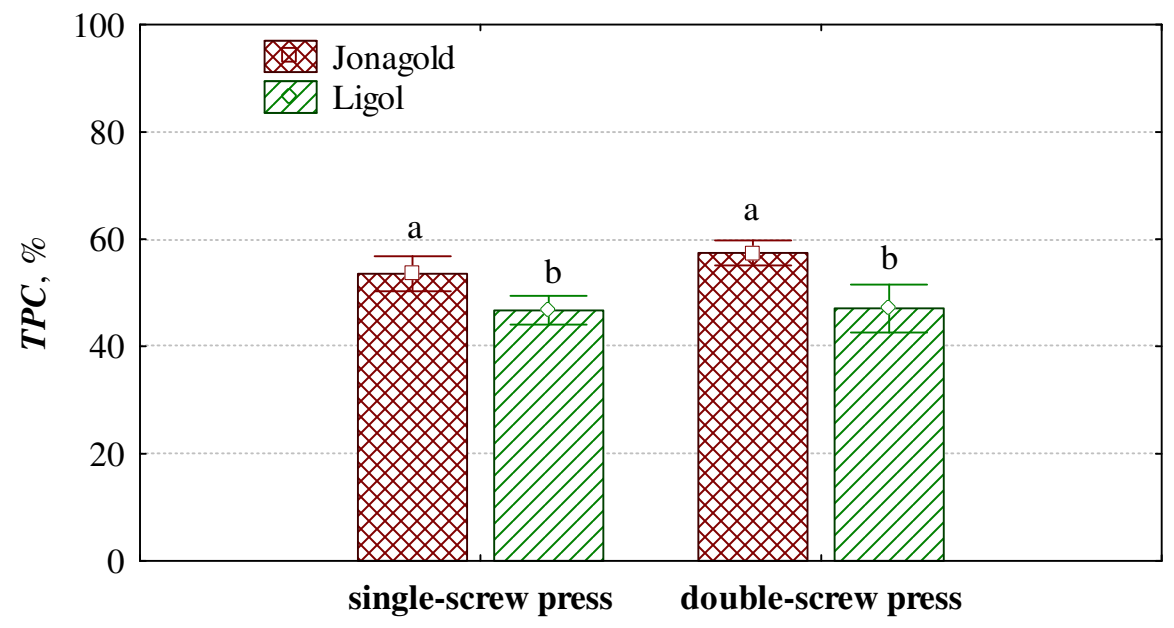

Fig. 3. Effect of press type on total phenolic content (TPC) in juice (filtrated juice)

The antioxidant capacity is a very important quality characteristic of juices. The effect of pulp pre-treatment on the antioxidant power is presented in Fig. 4. There was no influence of the type of the press on the antioxidant activity in the obtained juices. The content of polyphenols and their antioxidant activity can be a measure of the oxidation process and degradation of bioactive components during the extraction of fruit juices. According to Donaldson [18], a very sensitive way to measure the extentof oxidation and degradation is also the activity of selected enzymes (alpha-amylase and peroxidase). Research carried out by Donaldson [18] showed a very similar enzymatic activity of juices obtained using a single and twin screw press. This observation confirms the high quality of juices obtained using both screw presses.

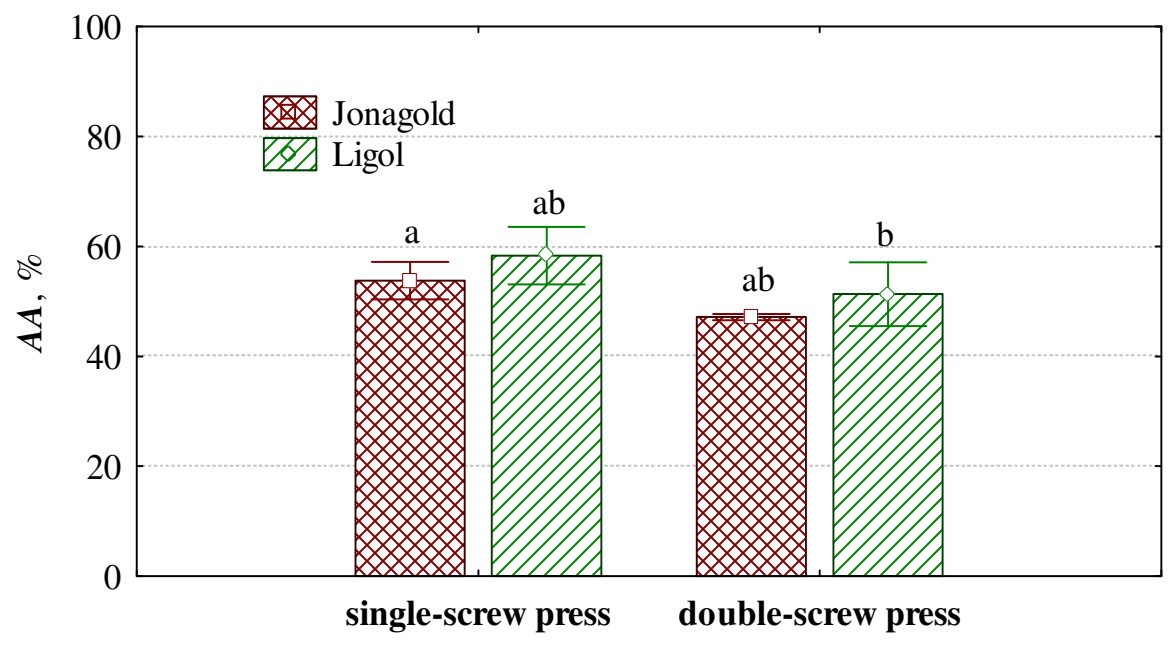

Fig. 4. Effect of press type on antioxidant activity $(\boldsymbol{A A})$ of juice (filtrated juice)

The type of the press used did not affect the extract content in the analysed juices. However, the juice produced from the tested varieties was characterised by different soluble solids content. The extract content in apple juices pressed industrially in Poland is at the level of 11.0-12.4 ${ }^{\circ} \mathrm{Bx}$ [15]. The extract content in the obtained juices exceeded the value of $10^{\circ} \mathrm{Bx}$, which indicates its suitability for juice production [16].

Acidity is one of the most important criteria in assessing the suitability of fruit for juice production. The statistical analysis showed that the type of press used did not affect the acidity of the 
juices obtained. Generally, the acidity of juices is significantly affected by varietal characteristics and fruit vegetation conditions [17]. Juices made of the tested apple varieties were characterised by an average $\mathrm{pH}$ of $3.66 \pm 0.09$ on the $\mathrm{pH}$ scale. According to literature data, the $\mathrm{pH}$ of apple juice varies from 3.37 to 4.24 [17] (Fig. 5).

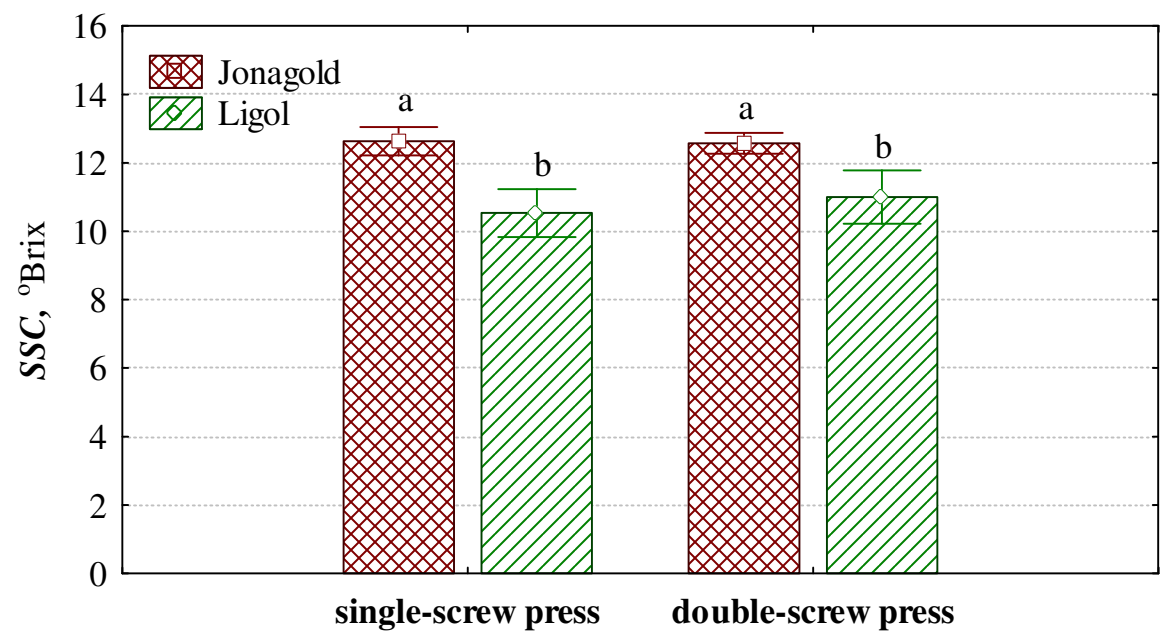

Fig. 5. Effect of press type on soluble solids content $\left({ }^{\circ} \mathbf{B x}\right)$ in juices (filtrated juice)

The raw juice immediately after pressing on the screw presses contains mechanical suspensions of various specific gravities formed from parts of tissues and cells. Although it contains many healthpromoting ingredients, the juice requires filtration even during producing of cloudy juices. After filtration, the density of the tested juice was a ta similar level regardless of the variety as well as the method of pressing and amounted to approximately $1037.7 \pm 3.73 \mathrm{kgm}^{-3}$.

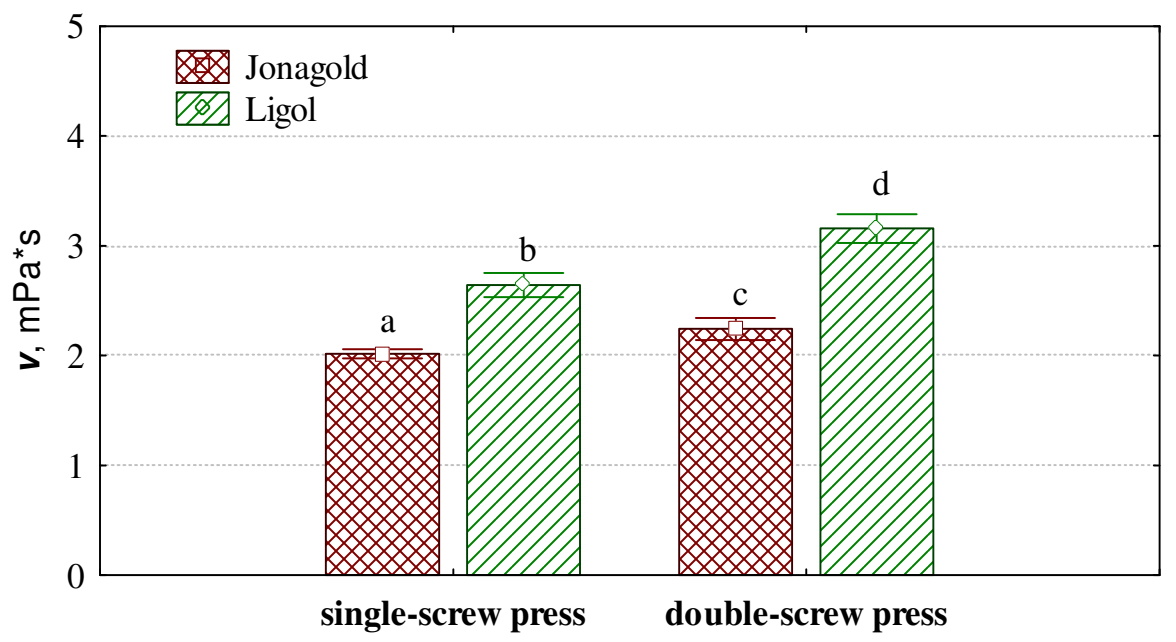

Fig. 6. Effect of press type on viscosity (pH) of (filtrated juice)

The study results demonstrated the effect of varietal characteristics of apples on the viscosity of the juice obtained. Regardless of the press type, a higher viscosity was determined in the juice from the Ligol variety. The viscosity of the juices obtained depended on the press type (Fig. 6). Viscosity of apple juice from the Jonagoldvariety was higher by $12.9 \%$, when the juice was obtained by means of the twin-screw press compared to the juice from a single-screw press. In the case of Ligol juice, the difference was greaterand amounted to $19.4 \%$.The higher viscosity of the juice extracted with the twin-screw press can be caused by greater breaking down and release of soluble phytochemical ingredients from apples.

\section{Conclusions}

The study indicates that the pressing efficiency depends on the design of the press. The highest yield of extraction was obtained for the twin-screw press. Under the experimental conditions, there 
was no influence of the press type on the quality properties of the juices, except for their viscosity. However, the quality characteristics of the juice depended on the apple variety. Higher contents of the extract and polyphenols were obtained in Jonagold juice and higher viscosity in the case of Ligoljuice. The conducted research indicates the necessity of further research on the use of screw presses for the production of juices with health-promoting properties.

\section{References}

[1] Shahidi F., Ambigaipalan P. Phenolics and polyphenolics in foods, beverages and spices: Antioxidant activity and health effects - A review. J Funct Foods 18, 2015, pp. 820-897.

[2] Yao L.H., Jiang Y.M., Shi J., Tomás-Barberán F.A., Datta N., Singanusong R., Cheng S.S. Flavonoids in food and their health benefits. Plant Food Hum Nutr 59, 2004, pp.113-122.

[3] Gwóźdź E., Gębczyński P. Prozdrowotne właściwości owoców, warzyw i ich przetworów (Prohealthy properties of fruits, vegetables and their preserves), Post Fitoter., nr (16)4, 2015, pp. 268-271 (In Polish).

[4] Markowski J., Baron A., Le Quéeré J.M., Plocharski W. Composition of clear and cloudy juices from French and Polish apples in relation to processing technology. LWT- Food SciTechnol 62, 2015, pp. 813-820.

[5] Pascuzzi S., Santoro F. Analysis of possible noise reduction arrangements inside olive oil mills: A case study. Agriculture (Switzerland), 7(10), 2017, 88. http://dx.doi.org/10.3390/agriculture7100088

[6] Pascuzzi S., Santoro F. Evaluation of farmers' OSH hazard in operation nearby mobile telephone radio base stations. 16th International Scientific Conference "Engineering for rural development" Proceedings, Volume 16. Jelgava, Latvia, May 24-26, 2017, pp. 748-755 - ISSN: 1691-5976, http://dx.doi.org/10.22616/ERDev2017.16.N15.

[7] Pascuzzi S., Santoro F. Exposure of farm workers to electromagnetic radiation from cellular network radio base stations situated on rural agricultural land. International Journal of Occupational Safety and Ergonomics, 21(3), 2015, pp. 351-358. http://dx.doi.org/10.1080/10803548.2015.1081774

[8] Nadulski, R., Kobus, Z., Wilczyński, K., Zawiślak, K., Grochowicz, J., Guz, T. Application of freezing and thawing in apple (Malus domestica) juice extraction. Journal of Food Sciences, 81(11), 2016, E2718-E2725.

[9] Tetik N., Karhan M., Turhan I., Aksu M., Oziyci H.R. A large-scale study on storage stability of cloudy apple juice treated by N2 and ascorbic acid. J Food Quality 36, 2013, pp. 121-126.

[10] Anifantis A.S., Colantoni A., Pascuzzi S., Santoro F. Photovoltaic and Hydrogen Plant Integrated with a Gas Heat Pump for Greenhouse Heating: A Mathematical Study. Sustainability 2018, 10, 378. http://dx.doi.org/10.3390/su10020378

[11] Singleton V.L., Orthofer R., Lamuela-Raventos R.M. Analysis of total phenols and other oxidation substrates and antioxidants by means of Folin-Ciocalteu reagent. Methods Enzymol 299, 1999, pp. 152-178.

[12] Brand-Williams W., Cuvelier M.E., Berset C.L.W.T. Use of free radical method to evaluate antioxidant activity. Food Science and Technology, 28, 1995, pp. 25-30.

[13] Vrhovsek U., Rigo A., Tonon D., Mattivi F. Quantitation of polyphenols in different apple varieties. J. Agric. Food Chem. 52, 2004, pp. 6532-6538.

[14] Wojdyło A., Oszmianski J., Laskowski P. Polyphenolic compounds and antioxidant activity of new and old apple varieties. J. Agric. Food Chem. 56, 2008, pp. 6520-6530.

[15] Kowalczyk R. Wydajność tłoczenia i wskaźnik zużycia jabłek w procesie wytwarzania zagęszczonego soku jabłkowego (The pressing capacity and the rate of apple consumption in the process of producing concentrated apple juice). Probl Inż Spoż 12, 2000, pp. 20-30 (In Polish).

[16] Gasik A., Mitek M., Ginalski Z., Krysztoforski M.A., Lesisz J.T., Sałata B., Sazońska B., Śliwa A. Przetwórstwo owoców na poziomie gospodarstwa (Fruit processing at farm level). Centrum Doradztwa Rolniczego w Brwinowie Oddział w Radomiu, s. 80, 2012, ISBN 978-8360185-98-8 (In Polish).

[17] Eisele T.A., Drake S.R. The partial compositional characteristics of apple juice from 175 apple varieties. J Food Compos Anal 18, 2005, pp. 213-221.

[18] Donaldson M., Comparison of juice extractors: Enzymes, Hallelujah Acres Foundation, Shelby, NC. 1998. 